\title{
THE OCCURRENCE OF TWIN EMBRYOS, ABNORMAL MORPHOLOGIES AND TEST REPAIR IN LOWER CRETACEOUS ORBITOLINIDAE (LARGER BENTHIC FORAMINIFERA): EXAMPLES FROM FRANCE, SOMALIA, IRAN, TIBET, AND TEXAS
}

\author{
Felix Schlagintweit
}

Received: 27 November 2019 / Accepted: 10 January 2020 / Published online: 20 January 2020

\begin{abstract}
Specimens displaying unusual ("abnormal" or aberrant) test morphologies, for example, the presence of twin embryos, or test repair after damage, are reported from Lower Cretaceous Orbitolinidae. Twin embryos (which have not always been recognized as such in the literature) are described from the upper Barremian of Tibet and France (Palorbitolina lenticularis), the upper Albian of Somalia (Orbitolina gr. sefini), and the upper Aptian-early Albian of Texas (e.g., Mesorbitolina texana). Twin embryos have so far only been reported from the Orbitolininae (with complex embryo), and not from the Dictyoconinae (with simple embryo). Repaired partially damaged tests (the damage possibly caused by predation or mechanical fracture) are observed in lower Aptian orbitolinids from Iran. Regeneration after damage (bioadjustment) leads to malformed tests.
\end{abstract}

Keywords: Larger Foraminifera, twin embryo, test abnormalities, teratology, Lower Cretaceous, Orbitolinidae

\section{INTRODUCTION}

The occurrence of unusual ("abnormal") test morphologies in larger benthic foraminifera may have different origins, for example, the occurrence of plurilocular embryonic apparati, recoveries after test damage (e.g., predation, mechanical fracture), or fusion ("conjoined") (e.g., Hageman \& Kaesler, 2002; Culver \& Lipps, 2002; Ferràndez-Cañadell et al., 2014; Briguglio et al., 2016). Extreme environmental conditions (e.g. sea-water chemistry, temperature) or deterioration (e.g., pollution) are also discussed as causes of such abnormal morphologies in ancient (e.g., Ramalho, 1971) and modern marine settings (e.g., Meriç et al., 2005; Sujata et al., 2011). Besides environmental causes, reproductive abnormalities (twin, triplet, quadruplet occurrences) are interpreted as being linked to genetic accidents (e.g., Meriç et al., 2008). The branch of science that studies the occurrence, mechanisms and causes of general abnormal developments (or malformations) is teratology (e.g., Moore and Persaud, 2008). The term "teratologic individual" has been used in the study of larger foraminifera for almost one hundred years (e.g., Douvillé, 1924; Vaughan and Cole, 1941, p. 67). Within this category, pluriembryonal embryonic apparati are also named twin (or Siamese twins) in the case of two (e.g., Benedetti, 2015) and multi embryos in the case of more than two. Briguglio et al. (2016) reported the occurrence of at least 16 embryos in one adult specimen of modern Cycloclypeus Carpenter. For further details about the causes and mechanisms of twin embryo development see Ferràndez-Cañadell et al. (2014) and Benedetti (2015). Pluriembryonal embryonic apparati have been observed in Paleozoic fusulinids (Wilde, 1965), mid-Cretaceous alveolinids (Hottinger, 1974; Özgen-Erdem et al., 2003; Mathieu et al., 2011), Upper Cretaceous-Paleogene orbitoidal larger foraminifera (orbitoidids, orthophragminids, lepidocyclinids) (Meriç, 1964, 1970, 1971, 1973; 1992; Omana et al., 2012; Bene- detti, 2015), and recent taxa such as Cycloclypeus (Briguglio et al., 2016). More rarely, they have also been reported from agglutinating taxa, such as Upper Jurassic spirocyclinids (Ramalho, 1971; Fig. 1) or Lower Cretaceous orbitolinids (Douglass, 1960; Hofker 1963).

This contribution aims to describe some examples of multiple embryos and unusual test morphologies ascribed to damage and subsequent test repair as observed in Lower Cretaceous Orbitolinidae. It is intended to bring these rarely noticed poorly described phenomena to the attention of researchers working on orbitolinid-bearing Cretaceous shallow-water carbonates.

\section{UNUSUAL TEST MORPHOLOGIES IN ORBITOLINIDAE}

The following examples of unusual test morphologies have been observed in random thin-sections of shallowwater carbonates either from previous publications (France, Tibet, Somalia, Texas) or from own material (Iran). The observed phenomena refer to twin embryos, abnormal test morphologies (e.g., Henson, 1948), and to test damage/fracturing and subsequent repair.

\section{Twin embryos}

\section{Examples from the upper Barremian of Tibet}

Fig. 2a-b

Orbitolinids with twin embryos are present in material from the Langshan Formation of the Lhasa Block, Tibet (Zhang, 1982; Rao et al., 2015). Zhang (1982, Plate 7, figs. 1, 7, re-illustrated here in fig. 2a-b) illustrated two specimens of Palorbitolina lenticularis (Blumenbach) showing twin embryos. In both specimens the overall low-conical morphology is more or less preserved. In one specimen (Fig. 2a), where the axes of the two embryos are diverging at an angle of $\sim 60$ degrees, a growth of the 


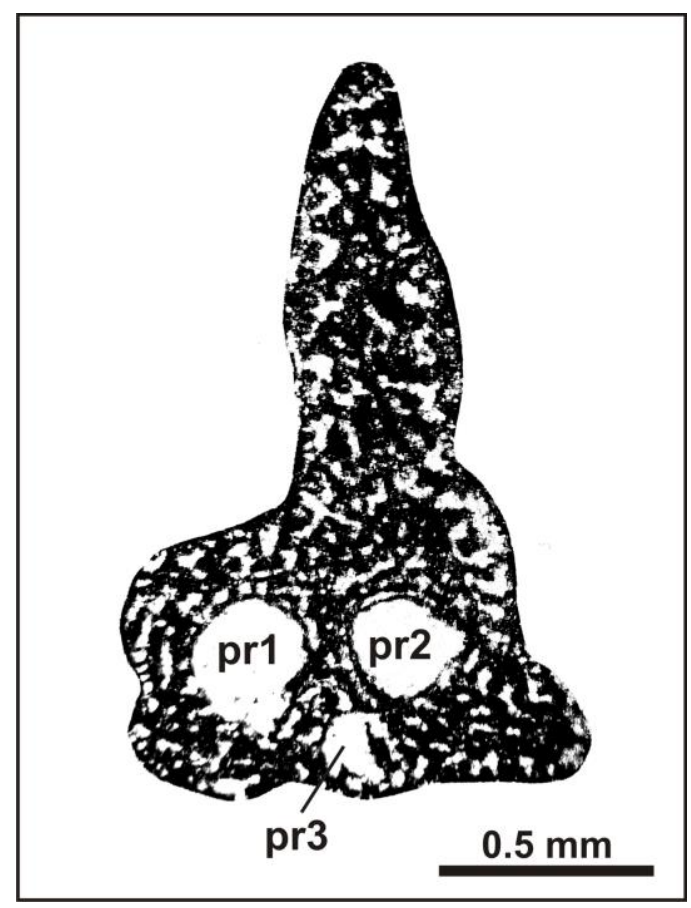

Fig. 1 Triple embryos in the agglutinating spirocyclinid Anchispirocyclina lusitanica (Egger), from the Tithonian-early Berriasian of Portugal (modified from Ramalho, 1971, pl. 15, fig. 6). The specimen displays a branching habitus with three branches each corresponding to one proloculus (pr1 to pr3).

"shared" test in two directions is observable. This specimen also shows a small double boss at the apex resulting from the two embryos. The two proloculi of this specimen have (inner) diameters of $0.17 \mathrm{~mm}$ (pr1) and 0.22 $\mathrm{mm}$ (pr2). The other specimen (Fig. 2b) displays almost parallel axes of their embryos $(0.17 \mathrm{~mm}$ for $\mathrm{pr} 1$, and 0.19 $\mathrm{mm}$ for $\mathrm{pr} 2$ ). In both specimens some minor discrepancies in the size of the twin embryos and the periembryonic ring (or chambers; see Schroeder, 1963, for details) are present. Whether these differences really exist or are simply due to different cutting planes remains uncertain. In any case, the diameters are in the normal range reported from Palorbitolina lenticularis (Schroeder, 1963; Gušić, 1981). It is also unclear from the two oblique sections whether the two embryonic apparati are directly attached or are separated by some post-embryonic chambers. Due to the obliquity of the section plane, no additional information on the neanic stage is observable.

\section{Examples from the upper Barremian of France} Fig. 2c-d, f

Twin specimens of Palorbitolina lenticularis (Blumenbach) are reported by Hofker (1963) in a subsurface sample from the Aquitaine Basin, southwestern France (Hofker, 1963, fig. 1, oil exploration well Lugos 2). The age of the sample was indicated by Hofker (1963) as uppermost Barremian. Like the Tibetian specimens, those from southwestern France shows two fully developed embryonic apparati with the two proloculi oriented either in the same plane and arrangement (Fig. 2c), slightly inclined to each other (Fig. 2d), or slightly shifted but with same orientation of the axes (Fig. 2f). In the specimens shown in Fig. 2c and 2d, the two embryonic apparati are clearly separated from each other by some postembryonic chambers.

\section{Examples from the late Aptian-early Albian of United States of America (Texas)}

Fig. 2e, g-h

Hofker (1963, pl. 16, fig. 1) describes a twin specimen of Mesorbitolina texana (Roemer) from the Glen Rose Formation of Texas. Hofker indicated a late Aptian or early Albian age (see also Douglass, 1960, and Scott, 2002, for further information). The specimen is an axial section where the two obliquely-set embryos are directly attaching each other laterally along their supra- and subembryonic zones (Fig. 2e). Between the two embryos there is a slight elevation forming an apical knob (possibly a third embryo out of the plane of section). Isolated specimens of Mesorbitolina texana displaying multiple (even up to 4 ? embryos) from the Glen Rose Limestone were illustrated by Douglass (1960, pl. 4, figs. 13-15). Another specimen of a twinned Mesorbitolina from the Glen Rose Limestone (Douglass, 1960, pl. 6, fig 6) with plane bases of the proloculi (see Schlagintweit \& Wilmsen, 2014) is reillustrated here as Fig. 2G. In this case, the two embryos are oriented 180 degrees to each other and are slightly displaced laterally. The two embryos are in lateral contact along their sub- and supraembryonic zones. The twinned Mesorbitolina sp. shown in Fig. 2h (Douglass, 1960, pl. 7 , fig. 5) represents a horizontal section passing the two embryos at different levels (left, through the proloculus; right, just the supraembryonic zone).

\section{Example from the upper Albian of Somalia}

Fig. $2 \mathrm{i}$

A specimen of Orbitolina gr. sefini Henson has been illustrated by Luger (2018, pl. 8, fig. 9, from the upper Albian Tisje Formation at Biyo Kulule northern Somalia (Fig. 2i). The twinned specimen is an axial section where the two embryonic apparati, both equal in size, are directly touching each other along their subembryonic zones (Schroeder, 1962, for details of terminology). The test growth then continues in two divergent directions leading to a two-dimensional test outline of a bow-tie. The two "cone bases" each with a weak concave depression are directly opposing each other. The normal growth direction of a specimen with a single embryo would be a direct continuation of the embryo axis. In contrast to the examples of Palorbitolina from Tibet, the twin test of the Somali specimen is bilaterally symmetrical along a median plane. The resulting morphology is that of two cones, fused at their apizes, resembling an hourglass. A similar form has been illustrated from a twin specimen of Palorbitolina lenticularis (displaying one embryo) from the Lower Aptian Kharaib Formation of Oman by Pittet et al. (2002, Fig. 4c).

\section{Example from the lower Aptian of Iran}

Fig. 2j

A specimen of an indeterminate orbitolinid is represented in an oblique section that does not cut the embryos (Fig. $2 \mathrm{j}$ ). The twin character of the specimen is evident by the 


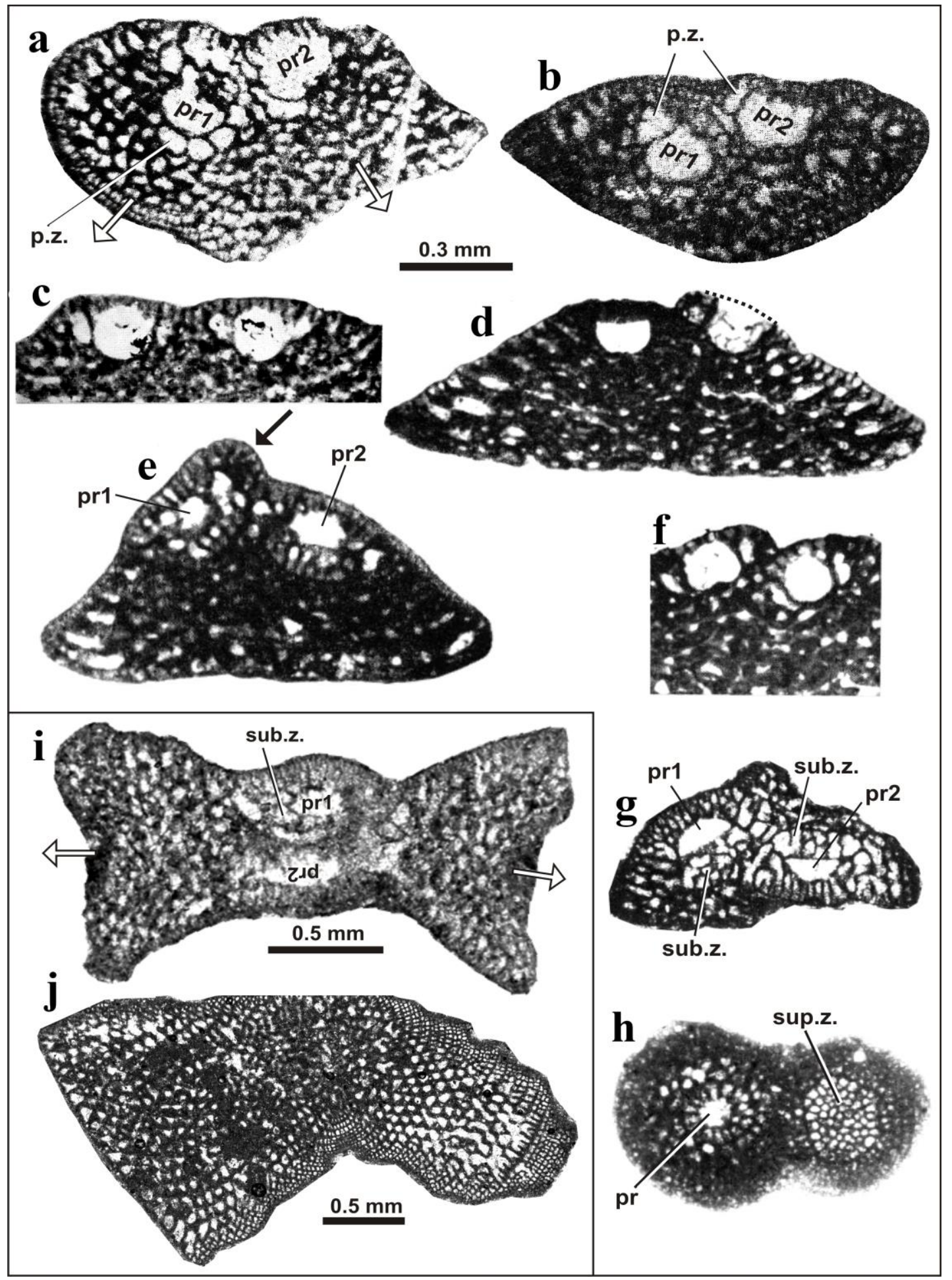

Fig. 2 Twin embryos in Cretaceous Orbitolinidae as a cause for test abnormalities. a-b Palorbitolina lenticularis (Blumenbach), upper Barremian of Tibet (extracted and modified from Zhang, 1982, pl. 7, figs. 1, 7). c-d, f Palorbitolina lenticularis (Blumenbach), upper Barremian of France (extracted and partly modified from Hofker, 1963, pl. 1, fig. 5, pl. 2, figs. 11, 7, 12). e Mesorbitolina texana (Roemer), axial section, with two embryos inclined to each other causing an irregular knob at the apex that might belong to a third not sectioned embryo (extracted from Hofker, 1963, pl. 16, fig. 1); upper Aptian-lower Albian of Texas (Glen Rose Limestone). g, Twinned Mesorbitolina displaying planar base of proloculus (see Schlagintweit \& Wilmsen, 2014). Embryos are rotated against each other and fused at their sub- and supraembryonic zones. Note the irregular apical knob, possibly referring to a third and not sectioned embryo (extracted and modified from Douglass, 1960, upper Aptian-lower Albian of Texas, Glen Rose Limestone). $\mathbf{h}$ Twinned Mesorbitolina sp., horizontal section passing the two embryos at different levels (left one with proloculus, right just the supraembryonic zone) (extracted and modified from Douglass, 1960, pl. 7, fig. 5, upper Aptian-lower Albian of Texas, Glen Rose Limestone). i Orbitolina gr. sefini Henson, upper Albian of Somalia (extracted and modified from Luger, 2018, pl. 8, fig. 9). j Orbitolinid indet., lower Aptian Taft Formation of Iran. The oblique section does not pass through the two embryos. The two diverging growth directions and the corresponding "cone bases" are visible. Abbreviations: $\mathrm{pr}=$ proloculus; p.z. $=$ peri-embryonic zone $($ or ring), sub.z. $=$ subembryonic zone, sup.z. $=$ supraembryonic zone, white arrows $=$ growth direction. 
two different growth directions and the two diverging "cone bases". The specimen is from the lower Aptian (Bedoulian) Taft Formation of Central Iran, the same material with the form showing test damage and repair discussed in a subsequent section.

\section{Abnormal test morphologies}

\section{Example from the upper Barremian of southwestern France}

Fig. 3

Hofker (1963, pl. 2, fig. 7) illustrated a specimen of Palorbitolina lenticularis with an unusual saddle-shaped morphology (concave "upper" side, convex "lower" side). A relatively large proloculus is situated in the median plane and two peri-embryonic zones (or rings) are present laterally (Fig. 3). The available two-dimensional view does not provide an unambiguous explanation. It could either correspond to a single shared proloculus (with two peri-embryonic rings) or a twin embryo where the second proloculus is situated outside the plane of the section. This "low concave-convex" specimen adds to the morphological inventory of the Orbitolinidae provided by Henson (1948, text-fig. 12), and can also be termed a swallowtail type. The morphology of the isolated specimen of Mesorbitolina texana illustrated by Douglass (1960) in his plate 4, figure 13 with bilateral symmetry is similar to the specimen of Palorbitolina lenticularis (Blumenbach) from Hofker (1963), but with a plane upper surface. These are just two examples that confirm Henson's (1948, p. 48) conclusion that "shape and size alone are not as a rule adequate criteria for determination and classification of Orbitolinae".

\section{Test damage and repair}

There are examples of abnormal test growth that clearly result from partial test damage or fracture of unknown origin and its subsequent repair. It documents that whatever caused this "injury" was not fatal and growth continued afterwards. The causes are purely speculative. Partial damage due to hydrodynamic energy can most likely be excluded as the specimens are from a wackestone facies. Another possibility would be traces of predator attack (e.g., bite marks). Such effects are difficult to be assessed accurately in modern forms (e.g., Rosina and Sengupta, 2019), and even more so in the fossil record.

\section{Example from the Lower Aptian of Iran}

Fig. 4

The illustrated (sub)axial section belongs to an indeterminate orbitolinid species (Fig. 4). It has been sampled from the Lower Aptian of the Taft Formation of Central Iran (Schlagintweit et al., 2013, Anarak section). The specimen displays partial damage on the right side with a penetration depth (as measured from the section) of about $0.25 \mathrm{~mm}$. It affects the marginal zone and the zone with radial main partitions only, but does not reach the central zone. After this incision, growth continued with the formation of new chambers showing the same structural zonation as before (e.g., 1-2 rafters in the marginal zone). 46
With respect to the unaffected opposite side, however, the apical angle changed, becoming lower. This individual thus tried to achieve its genetically inherited morphology, despite being damaged. In order to accomplish this, the chambers are bending upwards. Approximately at the time when test growth reached the plane of the former (= before the partial damage happened) test surface, the individual died. As a consequence of the repair process, the resulting cone morphology shows an irregular base with an oblique upward shift along the side that was damaged.

\section{DISCUSSION}

\section{General remarks}

Concerning the agglutinating conical Orbitolinidae, multiple embryos have in some cases not expressis verbis been recognized as such (Luger, 2018), in other cases they have been clearly identified as such structures (Hofker, 1963; Douglass, 1960). Douglass (1960) did not provide further comments or discussion of this rare phenomena. Concerning the twins of P. lenticularis, Hofker (1963, p. 215) remarked that "when the proloculi are close together it is still not possible to determine whether they are fused together in an embryonic or in a postembryonic stage". In the orbitolinid examples, the production of two embryos also results in an aberrant outer test morphology linked to the position of the embryonic chambers at or near the apex. In contrast, twin embryos in the involute planispiraly coiled alveolinids do no result in aberrant outer test morphologies, and are only visible in thin-sections (Hottinger, 1974; Özgen-Erdem et al., 2003; Mathieu et al., 2011).

\section{Remarks on palaeoenvironmental factors}

For the Oligocene large rotaliid genus Nephrolepidina, Benedetti (2015) argued that different reproductive strategies (asexual vs. sexual) occur along a depth gradient. In such cases twin embryos are statistically more frequent in stressed environments "that in unpolluted conditions correspond to the shallower (higher water illumination, salinity and temperature) and deeper (lower water motion, illumination and temperature) distribution of a taxon" (Benedetti, 2015, p. 15). Ramalho (1971, p. 148) argued that the multiple embryos observed in the large spirocyclinid species Anchispirocyclina lusitanica (see Fig. 1) were caused by palaeoenvironmental change. In the Lusitanian Basin of Portugal, these forms appear around the Tithonian-Berriasian boundary ("Purbeckian") where very shallow-water partly brackish conditions occur with the presence of abundant charophytes and ostracods (Ramalho, 1971, p. 148; 2015, p. 13). The reasons for the twin embryos from the Lower Cretaceous Orbitolinidae presented herein, however, are not determinable from the associated published information. No information is known about the percentage of abnormal tests in the investigated populations, nor is other pertinent sample information available (e.g., lithology, accompanying biota). Furthermore, the abundance of Orbitolinidae in the material (e.g., in Orbitolina Limestones) is unknown. Orbitolinidae are generally more confined to shallow-water areas, but for Palorbitolina for instance, a wider 
a
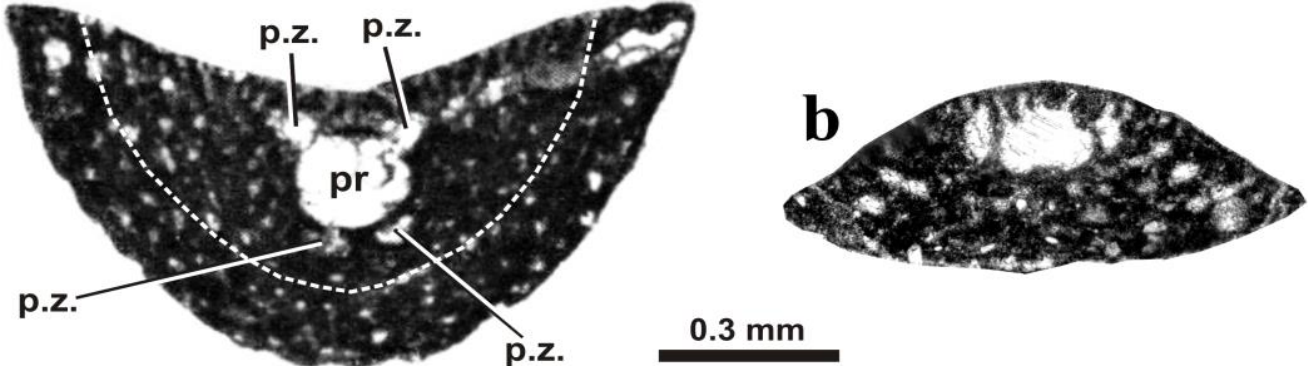

$0.3 \mathrm{~mm}$

Fig. 3 Abnormal (concave-convex) and normal (bi-convex) specimens of Palorbitolina lenticularis (Blumenbach). a Axial section of a specimen with one comparably large proloculus (pr) and two well separated peri-embryonic rings or zones (p.z.) (extracted from Hofker, 1963, pl. 2, fig. 7, upper Barremian of southwestern France, same sample that contains the twin embryos illustrated here in Fig. 1C-D, F). The white dotted line refers to one chamber. b Axial section showing proloculus surrounded by a periembryonic zone or ring (p.z.), upper Barremian or lower Aptian of Helvetic Schratten Limestone (Amden, Switzerland) (author's own material).

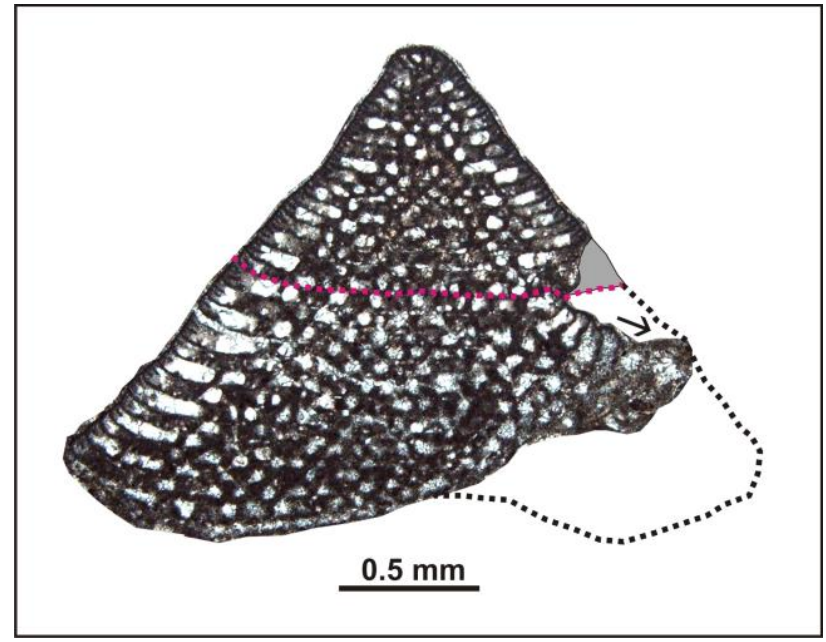

Fig. 4 Partial test damage and subsequent repair (bioadjustment sensu Hageman and Kaesler, 2005) in Orbitolinidae from the lower Aptian Taft Formation of Central Iran (Yazd area). The grey shaded area on the right side refers to the damaged test part. From the dotted red line onwards, repair started. Note the change of the apical angle (arrow) in order to achieve the imaginary cone surface (black dotted line). This abnormal growth resulted in a distinctly oblique test base shifted away from the original conical morphology (black dotted line at the base).

environmental range including also outer shelf facies in transgressive regimes is possible (Vilas et al., 1995). Whether this might explain the more frequent record of twin embryos observed in Palorbitolina is unclear.

The material from Hofker (1963) can be considered as a statistically quite exceptional accumulation of twinned Palorbitolina. In fact, Hofker (1963, pl. 1, fig. 5, pl. 2, figs. 3, 6, 11-12) illustrated six twin specimens, and also the specimen showing the abnormal embryonic apparatus with one proloculus bordered by two periembryonic rings (Hofker, 1963, pl. 2, fig. 7) all derived from the same sample. However, no information is available about the percentage of abnormal tests in the investigated populations and other pertinent sample data (e.g., lithology, accompanying biota) is lacking. The same is true for the Tibetian occurrences of twinned Palorbitolina (Zhang, 1982). Apart from the twinned Palorbitolina from south western France and Tibet, there also seems to be a potentially statistically significant accumulation of twinned Mesorbitolina in the uppermost Aptian-lower Albian Glen Rose Limestone of Texas (Hofker, 1963; Douglass, 1960).

\section{Remarks on taxonomy}

The observed examples of twin embryos are from megalospheric specimens of the genera Palorbitolina Schroeder, Mesorbitolina Schroeder, and Orbitolina d'Orbigny. These genera belong to the subfamily Orbitolininae Martin exhibiting complex embryos (Loeblich \& Tappan, 1987) and medium- to low-conical test morphologies. Twin embryos have not been reported from representatives of the medium- to high-conical subfamily Dictyoconinae Moullade with simple embryos (proloculus, with or without deuteroconch, no septules). Many dictyoconinids display palaeogeographically restricted occurrence (endemism, bioprovincialism), whereas orbitolininids have a wide, almost cosmopolitan geographic distribution (e.g., Cherchi et al., 1981; Pelissié et al., 1982; Moullade et al., 1985). This apparent difference between the two subfamilies is explained by Moullade et al. (1985), that besides a wider palaeoenvironmental tolerance of the Orbitolininae, their reproduction modes were distinct. Moullade et al. (1985) assumed a pelagic initial stage for the complex embryo of the Orbitolininae allowing flotation and thereby a wide dispersal by currents. Furthermore, Moullade et al. (1985) noted a greater proportion of microspheric specimens in populations of Orbitolininae as opposed to the dominance of megalospheric forms in assemblages of Dictyoconinae. It may be significant that the examples of twin embryos of the Orbitolininae presented herein are from the Lower Cretaceous, whereas no examples are known to the author from the Upper Cretaceous (post-Cenomanian-Turonian) or Paleogene orbitolinids. Post-Cenomanian orbitolinids taxa belong to the Dictyoconinae (Kaminski, 2014) except Karsella hottingeri Sirel (Schlagintweit, 2019). This certainly contributes to an explanation for the lack of any records of twinned post-Cenomanian orbitolinids. A final 
conclusion or further speculations are not possible on the basis of the literature examples presented herein.

\section{Remarks on damage and subsequent repair}

Partial test damage or fracturing and subsequent test repair has been reported from different groups of larger benthic foraminifera, e.g., fusulinids (Hottinger, 2006, Fig. 78E) or alveolinids (Hageman and Kaesler, 2005; Hottinger, 2006, fig. 78a-d), and are herein described from the conical agglutinating Orbitolinidae. Studying this phenomenon in Upper Permian fusilinids, Hageman and Kaesler (2005) distinguished two mechanisms related to the type (or amount) of breakage, bioplastering and bioadjustment. In the first case, major damage is repaired by rather rapidly secreted calcite more or less independently from the fusulinid test architecture. In case of minor, less severe damage, the repair takes place "in a more deliberate way that preserves in gross aspect the original architecture of the test....(and)...this often requires an unnatural-looking distortion of the size and shape of the repaired chambers" (Hageman and Kaesler, 2005, p. 183). In the case of the Lower Aptian orbitolinid from Iran (Fig. 4), the ,unnatural“" deformed test base and distortion of the repaired chambers, also accords with bioadjustment sensu Hageman and Kaesler (2005).

\section{CONCLUSIONS}

Orbitolinidae displaying twin embryos are reported from the upper Barremian to upper Albian-lower Cenomanian interval within the genera Palorbitolina Mesorbitolina, and Orbitolina. For the species Palorbitolina lenticularis, twin embryos were observed in specimens in both embryonic and post-embryonic stages. In the former case, one rather large-sized proloculus (with two periembryonic rings) is shared. The genera with observable twin embryos belong to the subfamily Orbitolininae characterized by complex embryonic apparati, whereas twins of the subfamily Dictyoconinae have so far not been reported. The latter are characterized often by restricted occurrences (bioprovincialism) whereas the Orbitolininae are widespread, almost cosmopolitan forms. There is no record of post-Cenomanian twinned orbitolinids in the literature. This might be because all Upper Cretaceous (= post Cenomanian) and Paleogene taxa belong to the Dictyoconinae. Test repair after damage is described from the conical-agglutinating Orbitolinidae and can be termed bioadjustment sensu Hageman and Kaesler (2005).

\section{ACKNOWLEDGEMENTS}

The manuscript benefitted from the very detailed reviews of Antonino Briguglio (Vienna) and Carles FerràndezCañadell (Barcelona). Further thanks (in alphabetic order) to Bruno Granier (Brest) who draw my attention to the twin embryos of Anchispirocyclina, Alexander Heyng (Aham) for permission to re-illustrate the original figure of Luger (2018), Mike Kaminski (Dharan) and Mike Simmons (London) for assistance with the English, and Koorosh Rashidi (Yazd) for the images from the lower
Aptian of Iran. Discussions with Andrea Benedetti (Tivoli) and Lorenzo Consorti (Trieste) provided stimulation.

\section{REFERENCES}

Benedetti, A., 2015. Twin embryos in the larger benthic foraminifer Nephrolepidina praemarginata. Journal of Mediterranean Earth Sciences, 7: 9-17.

Briguglio, A., Kinoshita, S., Wolfgring, E., Hohenegger, J., 2016. Morphological variations in Cycloclypeus carpenteri: Multiple embryos and multiple equatorial layers. Palaeontologia Electronica, 19.1.3A: 1-22. palaeo-electronica.org/content/2016/1404morphology-of-c-carpenteri

Cherchi, A., 2004. Evolution and palaeogeographic distribution of orbitolinids (larger Foraminifera) in the Urgonian carbonate platforms of SW Europe. Comparisons with Caribbean Tethyan species. Rocky Mountain (56 $6^{\text {th }}$ Annula) and Cordilleran (100 ${ }^{\text {th }}$ Annula) Joint Meeting (May 3-5, 2004), Paper No. 34-9.

Cherchi, A., Durand-Delga, M., Schroeder R., 1981. Apercu paléogéographique sur les Provinces à grands Foramninifères du Crétacé Inférieur dans le Cadre structural Méditerranéen. Rapports Commission International de la Mer Méditerranée, 27: 115-119.

Culver, S.J., Lipps, J.H., 2003. Predation on and by Foraminifera. In: Kelley P.H., Kowalewski M. and Hansen, Th.A. (Eds.) Predator-Prey Interactions in the Fossil Record. Kluwer Academic/Plenum Publishers, New York, 7-32.

Douglass, R.C., 1960. The foraminiferal genus Orbitolina in North America. Geological Survey Professional Papers, 333: 1-52.

Douvillé, H. (1924). Revision des Lépidocyclines. Mémoires de la Société Géologique de France, Mémoire 2, n. ser. 1: 1-50.

Ferràndez-Cañadell, C., Briguglio, A., Hohenegger, J., Wöger, J., 2014. Test fusion in adult foraminifera: a review with new observations of an early Eocene Nummulites specimen. Journal of Foraminiferal Research, 44 (3): 316-324.

Gušić, I., 1981. Variation, range, evolution and biostratigraphy of Palorbitolina lenticularis in the Lower Cretaceous of the Dinaric Mountains in Yugoslavia. Paläontologische Zeitschrift, 55: 191-208.

Hageman, S.A., Kaesler, R.I., 2005. Fusulinids: Predation damage and repair of tests from the Upper Pennsylvanian of Kansas. Journal of Paleontology, 76 (1): 181184.

Henson, F.R.S., 1948. Larger imperforate Foraminifera of south-western Asia. Families Lituolidae, Orbitolinidae and Meandropsinidae. Monograph British Museum (Natural History): 1-127.

Hofker, J., 1963. Studies on the genus Orbitolina (Foraminiferida). Leidse Geologische Mededelingen, 29 (1): 181-253.

Hottinger, L., 1974. Alveolinids, Cretaceous-Tertiary Larger Foraminifera. Esso Production ResearchEuropean Laboratories, Houston, Texas, 1-84.

Hottinger, L., 2006. Illustrated glossary of terms used in foraminiferal research. Carnets de Géologie / Notebooks on Geology, Memoir 2006/02 (CG2006_M02). 
Hottinger, L., Drobne, K., Caus, E., 1989. Late Cretaceous, larger, complex miliolids (Foraminifera) endemic in the Pyrenean Faunal Province. Facies, 21: 99-134.

Loeblich, A.R. Jr., Tappan, H., 1987. Foraminiferal genera and their classification, Van Nostrand Reinhold, New York, 2 vol., 970 p., 847 pls.

Luger, P., 2018. Mikropaläontologie (Foraminiferen, Ostrakoden), Biostratigraphie und fazielle Entwicklung der Kreide von Nordsomalia - mit einem Beitrag zur geodynamischen Entwicklung des östlichen Gondwana im Mesozoikum und frühen Känozoikum. Documenta Naturae Abhandlungen, Part 1 (text), 370 p., Part 2 (49 pls.).

Mathieu, R., Bellier J.-P., Granier, B., 2011. Manuel de Micropaléontologie. Carnets de Géologie, livre 2: 1123.

Meriç, E., 1964. A propos de la reproduction des Orbitoididae. Bulletin of the Mineral Research and Exploration Institute of Turkey, 63: 25-32.

Meriç, E., 1970. Schizogony in Orbitoides apiculatus var. gruenbachensis. Micropaleontology, 16: 227-232.

Meriç E. (1973). About the schizogony observed in Discocyclina archiaci (Schlumberger). Revista Española de Micropaleontología, 5, 403-408.

Meriç, E., 1992. Twin development in Discocyclinidae. Micropaleontology, 38: 310-312.

Meriç, E., Avsar, N., Görmüs, M., Bergin, F., 2005. Twin and triplet forms of Recent benthic foraminifera from the eastern Aegean Sea, Turkish coast. Micropaleontology, 50: 297-300.

Meriç, E., 1971. An additional aspect of reproduction in the Orbitoididae. Micropalaeontology, 17 (1): 99-104.

Meriç, E., Görmüş, M., Nielsen, J.K., Avşar, N., Ünsal, I., 2005. Significance of rare reproduction occurrences among recent nodosariids and other benthic foraminifera. Anales di Biología, 27: 85-100.

Meriç, E., Görmüş, M., Nielsen, J.K., Avşar, N., Yokeş, M.B., Dinçr, F., 2008. Twin, triplet and quadruplet teratogens from Antalya. Micropaleontology, 54 (34): 293-306.

Moullade, M., Peybernès, B., Rey, J., Saint-Marc, P., 1985. Biostratigraphic interest and paleobiogeographic distribution of Early and Mid-Cretaceous Mesogean Orbitolonids (Foraminiferida). Journal of Foraminiferal Research, 15: 149-158.

Nielsen, K.S.S., 1999. Foraminiferivory revisited: a preliminary investigation of holes in foraminifera. Bulletin of the Geological Society of Denmark, 45: 139142.

Omaña, L., Alencáster, G., Hernández, J.R.T., Doncel, R.L., 2012. Morphological abnormalities and dwarfism in Maastrichtian foraminifera from the Cárdenas Formation, Valles-San Luis Potosí Platform, Mexico: evidence of paleoenvironmental stress. Boletín de la Sociedad Geológica Mexicana, 64 (3): 305-318.

Özgen-Erdem, N., Ínan, N., Meriç E., 2003. Twin development in the foraminiferal genus Alveolina. Palaeontological Journal, 37 (3): 238-243.

Pelissié, T., Peybernès, B., Rey, J., 1982. Tectonique des plaques et paléobiogéographie des grands Foraminifères benthiques et des Algues calcaires du Dogger à
l'Albien sur le pour-tour de la Mesogée. Bulletin de la Societé geologique du France, (7) 24: 1069-1076.

Pittet, B., Van Buchem, F.S.P., Hillgärtner, H., Razin, P., Grötsch, J., Droste, H., 2002. Ecological succession, palaeoenvironmental change, and depositional sequences of Barremian-Aptian shallow-water carbonates in northern Oman. Sedimentology, 49: 555-581.

Ramalho, M.M., 1971. Contribution à l'étude micropaléontologique et stratigraphique du Jurassique supérieur et du Crétacé inférieur des environs de Lisbonne (Portugal). Serviços Geologicos de Portugal, Memoria 19: 1-204.

Ramalho, M.M., 2015. Stratigraphic micropalaeontology of the upper Jurassic neritic formations of Portugal and its Tethyan context. I - The Algarve Basin. Memórias Geológicas 35 : 1-111.

Rao, X., Skelton, P.W., Sha, J., Cai, H., Iba, Y., 2015. Mid-Cretaceous rudists (Bivalvia: Hippuritida) from the Langshan Formation, Lhasa Block, Tibet. Papers in Paleontology, 1 (4): 401-424.

Rosina, S., Sengupta, S., 2019. First record of parrotfish bite mark on larger foraminifera from the middle Eocene of Kutch, Gujarat, India. Current Science, 116 (3): 363-365.

Schlagintweit, F., 2020. Karsella hottingeri, Sirel, 1997 (Thanetian of Turkey): The first Paleogene "Orbitolininae". Iranian Journal of Geoscience Museum, 1 (2): 97-102.

Schlagintweit, F., Bucur, I.I., Rashidi K., Saberzadeh, B., 2013. Praeorbitolina claveli n. sp. (benthic Foraminifera) from the Lower Aptian sensu lato (Bedoulian) of Central Iran. Carnets de Géologie (Notebooks on Geology), Letter 2013/04 (CG2013_L04).

Schlagintweit, F., Wilmsen, M., 2014. Orbitolinid biostratigraphy of the top Taft Formation (Lower Cretaceous of the Yazd Block, Central Iran). Cretaceous Research, 49: 125-133.

Schroeder, R., 1962. Orbitolinen des Cenomans Südwesteuropas. Paläontologische Zeitschrift, 36 (34): 171-202.

Schroeder, R., 1963. Palorbitolina, ein neues Subgenus der Gattung Orbitolina (Foram.). Neues Jahrbuch für Geologie und Paläontologie Abhandlungen, 117: 346359.

Scott, R.W., 2002. Upper Albian benthic foraminifers new in West Texas. Journal of Foraminiferal Research, 32 (1): 43-50.

Sujata, K.R., Nigam R., Saraswat, R., Linshy, V.N., 2011. Regeneration and abnormality in benthic foraminifera Rosalina leei: Implications in reconstructing past salinity changes. Rivista Italiana di Paleontologia e Stratigrafia, 117 (1): 189-196.

Vaughan, T.W., Cole, W.S., 1941. Preliminary report on the Cretaceous and Tertiary larger foraminifera of Trinidad British West Indies. Geological Society of America special papers, 30: 1-137.

Vilas, L., Masse, J.P., Arias, C., 1995. Orbitolina episodes in acrnonate platform evolution: the early Aptian model from SE Spain. Palaeogeography, Palaeoclimatology, Palaeoecology, 119: 35-45. 
Wilde, G.L., 1965. Abnormal growth conditions in fusulinids. Cushman Foundation for Foraminiferal Research, 16: 121-124.

Zhang, B., 1982. Orbitolina (foraminifera) from Xisang. Series of the Scientific Expedition to the Qinghai -
Xisang Plateau. Palaeontology of Xisang, 4: 51-80 (in Chinese with English abstract). 